\author{
Martyna Żyła \\ Uniwersytet Ekonomiczny we Wrocławiu \\ e-mail: martyna.zyla@ue.wroc.pl
}

ORCID: 0000-0002-5146-5911

\title{
TEORIA SYGNALIZACJI W POLITYCE DYWIDEND NA PRZYKŁADZIE SPÓŁEK NOTOWANYCH NA NEWCONNECT
}

\section{SIGNALLING THEORY OF DIVIDENDS BASED ON THE EXAMPLE OF NEWCONNECT COMPANIES}

DOI: $10.15611 / \mathrm{e} 21.2018 .4 .08$

JEL Classification: D82, G14, G35

Streszczenie: Zgodnie z teorią sygnalizacji dywidendy mogą być dodatkowym sposobem na komunikowanie się spółki z inwestorami i przekazywanie im określonych informacji przez zarząd. Celem pracy jest sprawdzenie, czy za pomocą zmian w polityce wypłaty dywidend spółki notowane na rynku o wysokim poziomie asymetrii informacji - takim, którego przykładem jest alternatywny rynek akcji NewConnect, sygnalizują zmianę wyników i cen akcji. W konsekwencji dywidendy mogą być sposobem na ograniczanie kosztów agencji przez zarząd spółki. Początkowa próba wykorzystana w badaniach składała się ze wszystkich spółek, które były notowane na NewConnect w latach 2007-2015, z czego wyłoniono spółki regularnie wypłacające dywidendy. Jako regularną wypłatę dywidendy przyjęto płatności dokonywane przez minimum 5 lat z rzędu, jednak dozwolone było zawieszenie płatności na maksymalnie jeden rok.

Słowa kluczowe: hipoteza sygnalizacji, NewConnect, polityka dywidend.

Summary: According to the signaling theory, dividends can be an additional way for the company to communicate with investors and provide them with specific information by the management. The objective of the work is to check whether, through changes in the dividend policy, companies listed on the market with a high level of information asymmetry, such as alternative stock market NewConnect, signal changes in the financial results and share prices. Consequently, dividends can be used as a way to reduce agency costs by management of a company. The initial sample consisted of all companies that were listed on NewConnect in years 2007-2015, out of which there were selected companies that regularly (for a minimum of 5 years in a row) paid out dividends. Dividend payments that have been made for a minimum of 5 years in a row have been determined as regular payments, however it has been allowed to to suspend the payment for a maximum of one year.

Keywords: signalling hypothesis, NewConnect, payout policy. 


\section{Wstęp}

Alternatywne rynki akcji, zaliczane do rynków nieregulowanych zorganizowanych, umożliwiają pozyskanie kapitału na rozwój działalności przedsiębiorstwom, które na tradycyjnym rynku kapitałowym byłyby za małe i nie byłoby ich stać na pozyskanie kapitału lub na utrzymanie się jako spółka publiczna. Do takich rynków należy zaliczyć NewConnect, który funkcjonuje od 2007 r. i jest prowadzony przez Giełdę Papierów Wartościowych w Warszawie. Specyfika alternatywnych systemów obrotu (ASO) powoduje jednak występowanie znacznie większej asymetrii informacji w porównaniu z głównymi (regulowanymi) rynkami. Zgodnie z teorią sygnalizacji dywidenda może być dodatkowym sposobem na komunikowanie się z inwestorami i przekazywanie im przez zarząd informacji o spodziewanych wynikach finansowych. Obserwacja polityki dywidendowej emitentów pozwala akcjonariuszom na uzyskanie dodatkowych wiadomości na temat kondycji spółki, nieprzekazywanych bezpośrednio przez zarząd firmy w raportach finansowych. Redukcja asymetrii informacji skutkuje zmniejszeniem ryzyka inwestycji, podnosząc jednocześnie atrakcyjność rynku i podmiotów na nim notowanych, zwiększając ich szansę na pozyskanie kapitału. Istnieje wiele badań nad funkcją sygnalizacyjną polityki dywidend, jednak nieliczne z nich koncentrują się na rynkach alternatywnych, co skutkuje powstaniem luki badawczej na rynkach, które szczególnie są narażone na ryzyko asymetrii informacji. Poruszany problem wydaje się zatem istotny zarówno dla praktyki, jak i w ramach teorii finansów.

W artykule przedstawione zostaną wyniki badań mających na celu sprawdzenie, czy zmiany dokonywane w poziomie dywidend przez spółki notowane na rynku NewConnect, które wypłacały dywidendy regularnie, niosą ze sobą informacje o przyszłych wynikach finansowych i czy można je traktować jako sposób sygnalizowania przyszłej kondycji finansowej spółki. Zbadano również, jak informacja o zwiększeniu lub zmniejszeniu wypłacanej regularnie dywidendy wpływa na zachowanie cen akcji na rynku.

\section{Teoria sygnalizacji dywidend}

Za punkt wyjścia teorii sygnalizacji przyjmuje się występowanie asymetrii informacji między menedżerami spółki i akcjonariuszami mniejszościowymi. Inwestorzy zainteresowani daną spółką zazwyczaj mają problem ze znalezieniem wystarczająco wiarygodnych informacji dotyczących jej kondycji, na których podstawie mogliby podjąć świadomą decyzję inwestycyjną. Akcjonariusze nie są w stanie pozyskać informacji o obecnej i przyszłej sytuacji spółki w takim stopniu, w jakim posiada je zarząd, czy to ze sprawozdań finansowych, czy z bieżących komunikatów zarządu. Według teorii sygnalizacji wypłacane dywidendy zmniejszają poziom asymetrii informacji i są odbierane przez akcjonariuszy jako sygnał wysyłany na rynek przez menedżerów. Sygnały te mogą być traktowane jako sposób przekazywania informa- 
cji na temat obecnej kondycji spółki, a zmiana polityki wypłat dywidend może sugerować, w jakim kierunku będą zmieniać się przyszłe zyski.

Wynika to z przyjęcia założenia, że dywidenda jest traktowana przez zarządy firm jako koszt korzystania z kapitału własnego, który jednocześnie ogranicza możliwości inwestycyjne zarządowi. Poprzez dywidendę wytransferowywany jest z przedsiębiorstwa kapitał zazwyczaj w postaci wolnej gotówki. Zatem z tego powodu zarządy, gdyby miały na to wpływ, z pewnością nie decydowałyby się na wypłacanie dywidend i świadome pozbawianie się środków pieniężnych do dyspozycji i w przyszłości skazywanie się na pozyskiwanie dodatkowych środków pieniężnych poza spółką.

Zwiększenie wypłacanej dywidendy może zostać przyjęte jako zapowiedź polepszających się wyników w nadchodzących okresach, na co reakcją inwestorów będzie wzrost popytu na akcje, a w rezultacie wzrost ceny, natomiast obniżenie stopy dywidendy może zasugerować pogorszenie się sytuacji spółki. W obawie przed konsekwencjami wynikającymi z obniżenia dywidendy menedżerowie niechętnie zwiększają stopę wypłacanej dywidendy, jeżeli nie są przekonani co do stabilności zysków w przyszłości, nawet jeśli w obecnym okresie istnieje możliwość przekazania akcjonariuszom większej ilości środków. Niemniej trudno jednoznacznie stwierdzić, czy sama wiadomość o zmianie poziomu wypłaty ma wpływ na cenę akcji ze względu na korektę oczekiwań inwestorów co do przyszłych wyników, czy zmiana cen związana jest również z innymi czynnikami, takimi jak preferencje akcjonariuszy odnośnie do spółek z określoną polityką dywidend [Allen, Michaely 2003, s. 377-383].

Początku rozważań na temat efektu sygnalizacji dywidend upatruje się w koncepcji Lintnera, który w latach 50 . XX wieku przedstawił pracę, w której na podstawie wyników rozmów z menedżerami 28 starannie dobranych spółek stwierdził, że zwiększenie dywidendy jest zazwyczaj sygnałem o permanentnej zmianie poziomu zysku, a nie zapowiedzią wzrostu zysków w przyszłości. Jego zdaniem polityka dywidend w spółkach oparta jest na dążeniu do osiągnięcia docelowej wysokości wskaźnika wypłaty (autor stwierdził, że wskaźnik ten najczęściej bazuje na zysku netto) w długim okresie oraz na stopniowym dopasowaniu dywidendy do tego poziomu w kolejnych okresach. $\mathrm{Z}$ racji tego $\mathrm{w}$ przypadku przekonania menedżerów o stałej zmianie zysku na przestrzeni kolejnych lat spółki stopniowo dostosowywały wysokość wypłacanej dywidendy do momentu osiągnięcia docelowego poziomu wskaźnika, zamiast wprowadzić zmianę w całości w najbliższym okresie. Lintner twierdzi, że menedżerowie zwiększają dywidendy jedynie wtedy, gdy są pewni, że nie będą zmuszeni cofnać tej decyzji w przyszłości. Pozwala im to na uniknięcie ewentualnych skutków niepożądanych reakcji inwestorów w przypadku, gdy dalsze zmiany wypłacanej dywidendy okażą się nieuzasadnione [Lintner 1956, s. 97-113]. Miller i Modigliani w swoim artykule podkreślali występowanie tzw. zawartości informacyjnej dywidend (information content of dividends), jako że ich zdaniem zmiana stopy wypłacanej dywidendy ma wpływ na zmianę rynkowej ceny akcji 
spółki. Wspomniani autorzy twierdzą, że menedżerowie za pomocą wypłaty dywidendy mogą dawać sygnał o obecnej sytuacji finansowej i perspektywach rozwoju jednostki, przez co są w stanie zmienić oczekiwania inwestorów co do poziomu zysków w kolejnych okresach [Miller, Modigliani 1961, s. 411-433]. Pierwsze modele poświęcone efektowi sygnalizacji dywidend opracowali m.in. Bhatacharaya oraz Miller i Rock. W obu przypadkach podstawą badań było założenie występowania asymetrii informacji oraz założenie, że wypłata dywidendy wiąże się z koniecznością ponoszenia dodatkowych kosztów.

W przeprowadzonych badaniach empirycznych dotyczących efektu sygnalizacji autorzy analizowali głównie prawidłowość założenia, że zmianie wysokości wypłacanych dywidend towarzyszy zmiana zysków i/lub cen akcji spółki. Przykładowe badania przedstawiono $\mathrm{w}$ tabeli 1 .

Tabela 1. Badania nad efektem sygnalizacji dywidend

\begin{tabular}{|c|c|c|}
\hline Wyszczególnienie & Cena & Prognozy wyników \\
\hline $\begin{array}{l}\text { Zmiany wysokości } \\
\text { dywidend }\end{array}$ & $\begin{array}{l}\text { - } \text { Pettit [1972] } \\
\text { - Aharony, Swary [1980] } \\
\text { - Woolridge [1983] } \\
\text { - Dielman, Oppenheimer [1984] } \\
\text { - Lang, Litzenberg [1988] } \\
\text { - Amihud, Murgia [1997] }\end{array}$ & $\begin{array}{l}\text { - Watts [1973] } \\
\text { - Laub [1976] } \\
\text { - Grullon, Michaely, Swaminathan } \\
\text { [2002] } \\
\text { - Gou, Maung, Wilson [2015] }\end{array}$ \\
\hline Dywidendy inicjalne & $\begin{array}{l}\text { - Asquith, Mullins [1983] } \\
\text { - Dielman, Oppenheimer [1984] } \\
\text { - Healy, Palepu [1987] } \\
\text { - Michaely, Thaler, Womack [1995] }\end{array}$ & - Healy, Palepu [1987] \\
\hline $\begin{array}{l}\text { Zaprzestanie } \\
\text { (pominięcie) wypłat }\end{array}$ & $\begin{array}{l}\text { - Dielman, Oppenheimer [1984] } \\
\text { - Healy, Palepu [1987] } \\
\text { - Michaely, Thaler, Womack [1995] }\end{array}$ & $\begin{array}{l}\text { - Healy, Palepu [1987] } \\
\text { - Cowan, Sant [1994] }\end{array}$ \\
\hline
\end{tabular}

Źródło: opracowanie własne.

Pettit w swoim artykule potwierdził, że ceny rynkowe w pełni odzwierciedlają pozytywne i negatywne informacje związane z ogłoszeniem wysokości dywidendy. Znaczny wzrost cen rynkowych jest poprzedzony powiadomieniem o zwiększeniu wypłacanej kwoty, a obniżenie skutkuje spadkiem cen w dniu ogłoszenia informacji o wypłacie dywidendy oraz dzień po [Pettit 1972, s. 993-1007].

Watts dowiódł, że związek między zmianami przyszłych zysków i bieżącymi nieoczekiwanymi zmianami poziomu wypłat dywidend (czyli różnicą między obecnie wypłacanymi dywidendami a oczekiwaniami względem ich wysokości bazującymi na bieżących zyskach) jest pozytywny. Jednak wszystkie badania sugerują również, że bezwzględna wielkość przyszłych zmian zysków, na temat których informacje mogą być zawarte w nieoczekiwanych zmianach dywidend, jest bardzo mała. Ponadto badanie relacji między nieoczekiwanymi zmianami dywidend i cena- 
mi akcji wskazuje na zawartość informacji w dywidendach, przy czym uzyskane zmiany stóp zwrotu z akcji są na tyle niskie, że nie pokrywają kosztów transakcyjnych [Watts 1973, s. 191-211].

Laub w swojej pracy nawiązał do badań Wattsa, których poprawność zakwestionował. Autor na podstawie przeprowadzonych badań również potwierdził hipotezę mówiącą o tym, że ogłoszenie wypłaty dywidendy zawiera informacje na temat przyszłych wyników, które nie są zawarte w samych zyskach. Jednak zdaniem Lauba Watts w niewystarczającym stopniu rozpatrzył problem prognozowania wyników i niedostatecznie rozbudował ramy testowe dla hipotezy, przez co błędnie zinterpretował wyniki regresji, co spowodowało, że uzyskane przez niego wyniki były zaniżone [Laub 1976, s. 73-80].

Aharony i Swary w swoich badaniach sprawdzili, czy ogłoszenie wypłaty dywidendy w oderwaniu od opublikowania wyników finansowych zawiera dodatkowe informacje. Autorzy podzielili wyniki na trzy grupy: brak zmiany w wysokości dywidendy oraz ich zwiększenie i obniżenie. W przypadku pierwszej grupy inwestorzy nie uzyskali wyższej stopy zwrotu w badanym okresie. Akcjonariusze spółek, które zapowiedziały wzrost dywidendy, odnotowali pozytywną nadwyżkową stopę zwrotu głównie w dniu ogłoszenia informacji oraz dzień przed nim, a z kolei obniżenie dywidendy spowodowało uzyskanie negatywnej nadwyżkowej stopy zwrotu w tych samych okresach, przy czym zmiana stóp zwrotu dla spółek zwiększających dywidendę nastąpiła w większym stopniu niż w przypadku spółek podwyższających poziom wypłaty. Badania Aharony`ego i Swary`ego wskazują zatem, że ogłoszenie dywidendy dostarcza informacje na temat zmian w ocenie zarządu na temat perspektyw firmy [Aharony, Swary 1980, s. 1-12].

Asquith, Mullins zbadali wpływ dywidend na wartość akcji poprzez przeanalizowanie 168 firm, które wypłacają dywidendę po raz pierwszy lub wznawiają wypłatę po 10-letniej przerwie. Uzyskane przez nich wyniki potwierdzają wzrost wartości majątku akcjonariuszy, wynikający z inicjacji lub wznowienia płatności dywidendy [Asquith, Mullins 1983, s. 77-96].

Woolridge zbadał wpływ decyzji o zmniejszeniu lub zwiększeniu wysokości wypłacanych dywidend na wartość różnych klas papierów wartościowych. Oprócz oddziaływania dywidend na ceny akcji zwykłych autor uwzględnił również w swoich badaniach zachowanie cen akcji uprzywilejowanych i obligacji. Na podstawie zaobserwowanych zmian w wysokości dywidend w 225 losowo wybranych spółkach z NYSE autor potwierdził pozytywną korelację między wypłatą dywidendy i cenami analizowanych papierów wartościowych. Dodatkowo otrzymane przez niego wyniki wykazały spójność z hipotezą transferu kapitału między akcjonariuszami i obligatariuszami, co oznacza, że zwiększenie wypłacanej dywidendy będzie skutkowało przepływem kapitału posiadaczy akcji uprzywilejowanych oraz obligatariuszy do właścicieli akcji. Wyniki potwierdzają, że na skutek zmiany dywidendy podstawowym czynnikiem oddziałującym na wartość papierów wartościowych jest zawartość informacyjna dywidend, a efekt transferu kapitału nie może zostać wyklu- 
czony, jednak wpływa na ceny rynkowe w mniejszym stopniu niż efekt sygnalizacji [Woolridge 1983, s. 1607-1615].

Dielman i Oppenheimer skoncentrowali się na dużych zmianach w polityce dywidendowej, tj. przypadkach pominięcia wypłaty, wznowienia lub dywidendy inicjacyjnej, zwiększenia lub zmniejszenia poziomu wypłaty o co najmniej $25 \% \mathrm{w}$ porównaniu z zapowiadaną wcześniej dywidendą. Wyniki pokazały, że we wszystkich grupach występowały nadwyżkowe stopy zwrotu z akcji w dniu ogłoszenia wypłaty dywidendy oraz w pierwszym dniu po jej ogłoszeniu i utrzymują się one we wszystkich grupach, z wyjątkiem pominięcia płatności, przez około miesiąc po zdarzeniu. Autorzy stwierdzają, że ich wyniki świadczą o występowaniu zawartości informacyjnej dywidend, przy czym najsilniejszym dowodem na to jest przypadek pominięcia wypłaty. Autorzy są zdania, że im bardziej stabilna polityka dywidend firmy, tym większy spadek wartości akcji w przypadku pominięcia dywidendy [Dielman, Oppenheimer 1984, s. 197-216].

Związek zmiany w wynikach firmy z ogłoszeniem dywidendy inicjalnej lub pominięciem wypłaty dywidendy, a także spójność reakcji rynku na zmianę polityki dywidend analizowali Healy i Palepu. Otrzymane przez nich wyniki potwierdziły pozytywną korelację między dywidendą inicjalną $\mathrm{i}$ wzrostem zysków na pięć lat przed i dwa lata po ogłoszeniu pierwszej dywidendy, przy czym zmiany te były zazwyczaj permanentne. W przypadku pominięcia wypłaty dywidendy firmy odnotowywały znaczne spadki zysków dwa lata przed i rok po ogłoszeniu zaniechania wypłaty, jednak w tym przypadku spadki były jedynie tymczasowe. Anormalne reakcje cen akcji na skutek inicjacji lub zaniechania wypłaty dywidendy były skorelowane ze zmianami zysków firmy w roku ogłoszenia zdarzenia oraz w roku kolejnym. Ta zależność została stwierdzona po uwzględnieniu wcześniejszych zmian w zyskach i informacjach dostępnych na rynku w momencie zapowiedzi dywidendy. Na tej podstawie można stwierdzić, że dywidendy inicjalne i zaniechane zawierają informacje o przyszłych wynikach spółki [Healy, Palepu 1988, s. 149-175].

Lang i Litzenberg zbadali reakcje cen akcji na skutek zmiany wysokości wypłacanej dywidendy o co najmniej 10\%. Autorzy założyli, że jeżeli firmy mają tendencję do przeinwestowania, wtedy wzrost dywidendy zmniejszy poziom inwestycji i zwiększy rynkową wartość firmy. Natomiast spadek dywidendy sygnalizuje, że spółka będzie podejmować więcej mało rentownych projektów. Dla firm maksymalizujących wartość poziom inwestycji jest niezależny od dywidend. Według wyników autorów reakcja rynku na skutek ogłoszenia dywidendy jest większa dla spółek przeinwestowujących niż dla spółek maksymalizujących wartość. Średnia stopa zwrotu dla firm z nadmiernym poziomem inwestycji jest znacznie większa niż dla spółek maksymalizujących wartość. Tak więc rynek nagradza firmy, które decydują się na wypłatę (lub zwiększenie) dywidendy na skutek ograniczenia ich skłonności do inwestycji w mało rentowne projekty. Dodatkowo wyniki pokazują, że wpływ ogłoszenia dywidendy na oczekiwane zyski nie jest statystycznie istotny w przypadku zwiększenia lub zmniejszenia dywidend, co jest sprzeczne z hipotezą sygnalizacji [Lang, Litzenberger 1989, s. 181-191]. 
Cowan i Sant badali wpływ pominięcia wypłaty dywidendy na zmienność prognozowanych i bieżących zysków spółki. Autorzy porównali zyski i ich prognozy dla spółek, które pominęły wypłatę dywidendy w okresie 1963-1984, poprzez porównanie wariancji bieżących lub prognozowanych zysków na dwa lata przed zdarzeniem i dwa lata po zdarzeniu. Wyniki pokazały, że zmienność bieżących i prognozowanych zysków była znacznie większa po braku wypłaty. Potwierdza to hipotezę, że menedżerowie pomijają wypłatę dywidendy, gdy wyniki firmy stają się mniej przewidywalne, co oznacza, że dywidendy wykorzystywane są jako mechanizm sygnalizacji [Cowan, Sant 1994, s. 1113-1133].

Michaely, Thaler i Womack przeanalizowali krótkookresowe zachowania cen akcji w odniesieniu do ogłoszenia dywidendy inicjacyjnej lub pominięcia jej wypłaty, a także zachowanie cen w długim okresie po wystąpieniu tych zdarzeń. Analiza wyników dla trzydniowego przedziału czasowego wykazała, że spółki inicjujące dywidendę odnotowują nadwyżkową stopę zwrotu z akcji $(+3,4 \%)$ przy rocznej stopie wypłaty dywidendy $0,9 \%$. Pominięcie wypłaty skutkuje uzyskaniem ujemnej nadwyżkowej stopy zwrotu na średnim poziomie $-7,0 \%$. Ten znaczny spadek cen został odnotowany przy stopie dywidendy na poziomie $6,7 \% \mathrm{w}$ okresie poprzedzającym ogłoszenie zaniechania wypłaty dywidendy. Badania cen akcji w kolejnych trzech latach po wystąpieniu obu zdarzeń wykazują, że ceny akcji firm inicjujących dywidendę kontynuują wzrost $(+24,8 \%)$, a w przypadku pominięcia wypłaty ceny wciąż spadały $(-15,3 \%)$. Potwierdzono również to, że reakcje cen w krótkim i długim okresie są większe w sytuacji ogłoszenia wypłaty dywidendy inicjalnej niż w przypadku jej pominięcia. Dla krótkiego okresu jako przyczynę asymetrii przyjęto występującą różnicę w wielkościach zmian stóp dywidendy dla obu zdarzeń, natomiast dla długiego okresu autorzy nie znaleźli argumentu wyjaśniającego różnicę w sile reakcji rynku na zmianę polityki dywidendy [Michaely, Thaler, Womack 1995, s. 573-608].

Amihud i Murgia na przykładzie rynku niemieckiego i amerykańskiego przeanalizowali zawartość informacyjną dywidend na podstawie obserwacji reakcji cen akcji spółek po ogłoszeniu zmian w wysokości dywidend. Skoncentrowali się oni jednak na wpływie wysokości opodatkowania zysków z tytułu dywidendy i zysków kapitałowych na jakość informacji zawartych w dywidendach. Otrzymane wyniki wskazały, że zmiany wysokości dywidend powodują reakcję cen w takim samym kierunku na rynku niemieckim jak na amerykańskim, pomimo rozbieżnej polityki podatkowej, co według autorów wskazuje na to, że zmiany dywidend zawierają informacje, które mogą być wyjaśnione również przez inne czynniki niż opodatkowanie [Amihud, Murgia 1997, s. 397-408].

Grullon, Michaely i Swaminathan zweryfikowali zależność między zmianami stopy dywidendy oraz zmianami w systematycznym ryzyku firmy, na podstawie czego sprawdzono zawartość informacyjną zmian poziomu wypłacanych dywidend. Autorzy dodatkowo powiązali zmiany w polityce dywidend ze zmianami w cyklu życia spółki. Na podstawie otrzymanych wyników stwierdzono, że na skutek ogło- 
szenia wzrostu dywidendy zyski zamiast rosnąć, maleją, a zyski firm zmniejszających poziom dywidendy wykazują tendencję wzrostową. Po ogłoszeniu zwiększenia dywidendy ryzyko systematyczne firmy spada, co powoduje spadek kosztu kapitału firmy, jednocześnie wywołując pozytywną reakcję cen dla spółek zwiększających dywidendy, nawet jeśli zmiana ta zawiera informacje o spadku perspektyw rozwoju firmy. Uzyskane wyniki wskazują, że spółki zwiększają stopę wypłaty dywidendy w sposób permanentny, co jest zgodne z teorią wygładzania dywidend przedstawioną przez Lintnera. Wyjaśnienie zależności między zmianami poziomu wypłat dywidend i zmianami ryzyka autorzy tłumaczą na podstawie przedstawionej przez nich hipotezy dojrzałości (maturity hypothesis). Gdy firma dojrzewa, jej możliwości inwestycyjne maleją, powodując spadek ich przyszłej rentowności, jednak zdaniem autorów największą konsekwencją starzenia się firmy jest zmiana ryzyka systematycznego spowodowanego najczęściej mniejszymi możliwościami rozwoju firmy. Spadek możliwości inwestycyjnych dodatkowo powoduje akumulację wolnych przepływów pieniężnych, co prowadzi do wzrostu poziomu wypłacanych dywidend, a zatem wyższa dywidenda może wskazywać na dojrzałość firmy [Grullon, Michaely, Swaminathan 2002, s. 387-424].

Gou, Maung i Wilson przeprowadzili badania w celu sprawdzenia, czy wzrost dywidendy wpływa pozytywnie (negatywnie) na zmiany prognozowanych zysków, a zarazem tego, czy efekt ten jest mniejszy (większy) przy większych wahaniach bieżących zysków. Uwzględniając wahania zysków, autorzy potwierdzili pozytywną zależność między wzrostem dywidend a prognozowanymi wynikami, przy czym efekt jest złagodzony przez wyższą zmienność bieżących wyników. W szczególności w przypadku firm odnotowujących małe wahania zysków wzrost dywidendy sygnalizuje zwiększenie rentowności spółki. Dla firm, których wahania zysków są duże, podwyższenie dywidendy nie sygnalizuje wzrostu prognozowanych zysków, a obniżenie wahań przyszłych zysków. Autorzy nie otrzymali odpowiednich rezultatów, aby potwierdzić podobną zależność dla spółek zmniejszających dywidendy [Gou, Maung, Wilson 2015, s. 1-37].

\section{Asymetria informacji na rynku NewConncet}

Rozwój rynków kapitałowych daje coraz więcej możliwości pozyskania kapitału mniejszym spółkom niebędącym w stanie sprostać wymaganiom postawionym przez główne rynki giełdowe. Powstanie licznych nowych segmentów działających poza rynkiem regulowanym umożliwia wejście na giełdę małym i średnim podmiotom o dużych perspektywach wzrostu przy uproszczonych formalnościach oraz niższych kosztach wejścia i funkcjonowania w porównaniu z rynkiem głównym.

W 2007 r. warszawska Giełda Papierów Wartościowych uruchomiła platformę NewConnect dedykowaną małym i średnim przedsiębiorstwom znajdującym się we wczesnej fazie rozwoju, wpisując się zarazem w trend panujący na innych rynkach w Europie. Polski rynek w porównaniu z innymi rynkami alternatywnymi, pomimo 
przewagi pod względem liczby notowanych spółek, wciąż jest słabiej rozwinięty niż jego zagraniczne odpowiedniki. Na tle pozostałych rynków polska platforma obrotu zajmuje drugie miejsce pod względem liczebności emitentów, lecz dopiero siódme pod względem kapitalizacji. Wskazuje to na to, że NewConnect, mimo dużego zainteresowania ze strony emitentów, nie zdołał zyskać współmiernej przychylności inwestorów.

Uproszczone wymogi emisyjne i uczestnictwa w obrocie obowiązujące spółki obecne na NewConnect sprzyjają występowaniu większej asymetrii informacji w porównaniu z rynkiem regulowanym. Na ASO zaobserwować można kilka obszarów asymetrii informacji, które wynikają z różnicy pomiędzy konstrukcją prospektu emisyjnego i dokumentu informacyjnego, zakresu sprawozdawczości finansowej, a także różnicy w dostępie do informacji między akcjonariuszami większościowymi i mniejszościowymi.

Ułatwienie dostępu do rynku przez zmniejszenie wymogów informacyjnych wiąże się jednocześnie z mniejszą przejrzystością spółek notowanych na NewConnect. Ograniczenie informacji, którymi muszą dzielić się emitenci ASO, z punktu widzenia potencjalnych inwestorów jest dodatkowym czynnikiem ryzyka.

Wypłaty dywidend na NewConnect nie są często spotykanym zjawiskiem. Według teorii sygnalizacji dywidendy mogą informować o dobrej kondycji firmy i z tego względu na wypłatę powinny decydować się podmioty o silnej pozycji rynkowej. Biorąc jednak pod uwagę strukturę właścicielską emitentów, w przypadku których często właściciele większościowi pełnią funkcję członków zarządu danej spółki, można stwierdzić, że wypłata dywidendy może być sposobem na wytransferowanie pieniędzy ze spółki.

Większa asymetria informacji występująca na NewConnect powoduje podwyższenie ryzyka wynikającego z teorii agencji. Istnieją jednak metody występujące na innych rynkach, które umożliwiają ograniczenie kosztów agencji będących konsekwencją monitorowania działań spółek mającego na celu ograniczenie asymetrii informacji. Należą do nich:

- Pojawienie się inwestorów instytucjonalnych, co zazwyczaj wymusza na emitentach poprawę sprawozdawczości i komunikacji z rynkiem. Na NewConnect, w przeciwieństwie do np. włoskiego rynku alternatywnego, nie ma obowiązku udziału inwestora instytucjonalnego w akcjonariacie notowanej spółki.

- Wprowadzenie do spółki kapitału obcego powodujące, że bank staje się organem monitorującym działalność spółki. Jednak ze względu na to, że na NewConnect emitentami zazwyczaj są przedsiębiorstwa z krótką historią działalności lub pochodzące $\mathrm{z}$ branż innowacyjnych, dług wykorzystywany jest w ograniczonym stopniu lub nie występuje wcale.

- Zwiększenie poziomu ładu korporacyjnego i poprawienie jakości relacji inwestorskich, jednak w przeciwieństwie do spółek z rynku regulowanego emitenci NewConnect często nie są w stanie ponieść kosztów aktywnego prowadzenia relacji inwestorskich, a wysoka koncentracja właścicielska zazwyczaj nie zachęca do podwyższania poziomu ładu korporacyjnego. 
- Poprawa jakości publikowanych sprawozdań oraz zwiększenie zakresu ujawnianych informacji, których upublicznianie nie jest obowiązkowe. Według regulaminu ASO dopuszczalne jest dobrowolne upublicznianie sprawozdań miesięcznych, niemniej jednak jest to wykorzystywane przez niewielką liczbę emitentów. Ujawnienie większej liczby informacji wiąże się ze wzrostem kosztów zatrudnienia dodatkowego personelu księgowości, co dla małych spółek może być niemożliwe, a także z koniecznością umotywowania przed inwestorami wykonanych działań przedstawionych w dodatkowo opublikowanych informacjach.

- Wypłata dywidendy, która zgodnie z teorią sygnalizacji powoduje, że przedsiębiorstwo, dzieląc się zyskiem, może wysłać inwestorom informacje na temat swojej bieżącej kondycji. Dzięki temu dywidenda może być traktowana jako dodatkowy sposób komunikacji z akcjonariuszami.

Firmy notowane na rynku NewConnect powinny dążyć do redukcji występującej asymetrii informacji. Większa przejrzystość spółki sprzyja wzrostowi zaufania inwestorów do emitenta, co jednocześnie pomaga ograniczyć niepewność na rynku i zwiększyć płynność akcji. Prowadzi to do zmniejszenia ryzyka inwestycji, a z punktu widzenia spółki ułatwia uzyskanie w przyszłości dodatkowego finansowania na dalszy rozwój oraz obniża koszt pozyskania kapitału.

\section{Opis próby badawczej}

W okresie 2007-2015 na NewConnect weszło 541 spółek. Z obrotu wycofanych zostało 121 podmiotów, z czego 48 przeszło na rynek główny i ostatecznie na koniec 2015 r. notowanych było 418 spółek. Wszystkie spółki obecne na NewConnect na koniec 2015 r. oraz te, które przeszły na rynek główny, poddano analizie pod kątem prowadzonej przez nie polityki dywidend. Pierwsze wypłaty miały miejsce w 2008 r., a udział spółek dywidendowych od tego czasu zwiększał się co roku (z wyjątkiem 2011 r.), osiągając w 2015 r. poziom 15,55\%, gdy spośród 418 podmiotów ogółem $65 \mathrm{z}$ nich wypłaciło dywidendę.

W celu zbadania wpływu dywidend na wyniki finansowe podmiotów notowanych na NewConnect z dalszej analizy odrzucono firmy, które w latach 2007-2015 w ogóle nie wypłacały dywidendy lub płatności były nieregularne. Jako spółki regularne płacące dywidendy potraktowano emitentów, którzy w analizowanym okresie co roku dokonywali wypłat dywidendy przez co najmniej pięć następujących po sobie lat. W badaniach zaakceptowano również występowanie maksymalnie rocznej przerwy w wypłatach w ciągu tych pięciu lat.

$\mathrm{Na}$ podstawie opisanych kryteriów do dalszej analizy dopuszczono łącznie 11 przedsiębiorstw; były nimi: Automatyka-Pomiary-Sterowanie SA, Aqua SA, UHY ECA SA, Ekopol Górnośląski Holding SA, Euro-Tax.pl SA, Gwarant Agencja Ochrony SA, Makolab SA, Milkpol SA, Onico SA, PGS Software SA, Pharmena SA.

Dla wymienionych spółek przeanalizowano podstawowe dane finansowe $\mathrm{z}$ roku, w którym po raz ostatni została wypłacona dywidenda (2015 r.), oraz rok poprzedza- 
jący ostatnią wypłatę (2014 r.). Wyjątkiem jest spółka Milkpol, która ostatnią dywidendę wypłaciła w $2014 \mathrm{r}$.

Pod względem przychodów największą spółką jest Onico, której przychody znacznie odbiegają od średniej wartości wszystkich firm. W analizowanym okresie przychody Onico wzrosły o 74,03\%, przy średnim wzroście dla całej grupy badawczej wynoszącym $48,52 \%$. Przychody czterech podmiotów w roku wypłaty ostatniej dywidendy pogorszyły się w porównaniu z rokiem poprzednim.

Najwyższy zysk na działalności operacyjnej, tak jak w przypadku przychodów, generuje spółka Onico. W ostatnim roku wypłaty dywidendy zysk operacyjny powyżej średniej wartości uzyskały trzy firmy - Aqua, Onico, PGS Software. Również trzech emitentów odnotowało stratę na działalności operacyjnej (Milkpol, UHY ECA, Euro-Tax.pl), przy czym rok wcześniej stratę poniosła tylko jedna spółka (UHY ECA). Mediana wartości zysku operacyjnego zwiększyła się o 82,42\%.

W roku ostatniej wypłaty dywidendy największy zysk netto uzyskała spółka PGS Software, przy czym średni poziom zysku przekroczyły również dwie inne firmy - Aqua i Onico, którego wypracowany zysk netto przewyższył maksimum z poprzedniego roku o $20,73 \%$. Jeden emitent odnotował stratę netto w okresie wypłaty ostatniej dywidendy (Milkpol).

Spółka Aqua pod względem wielkości aktywów znacznie odstaje od średniej, przekraczając ją przeszło siedmiokrotnie. W analizowanym okresie pięć spółek zmniejszyło wartość aktywów w roku wypłaty dywidendy, a w pozostałych przypadkach wielkość ta była większa niż rok wcześniej, przy czym największy wzrost odnotowała firma Onico.

W badanych latach dwóch emitentów nie posiadało żadnych zobowiązań finansowych - Milkpol i Euro-Tax.pl. Pięć spółek zwiększyło wartość długu odsetkowego w okresie wypłaty ostatniej dywidendy, w tym w największym stopniu Onico.

Większość z analizowanych przedsiębiorstw jest rentownych, z czego najbardziej Makolab, Onico, Euro-Tax.pl, Gwarant i PGS Software. Ujemną rentowność kapitału własnego w ostatnim badanym roku odnotowała spółka Milkpol. Średnia wartość ROE dla wszystkich firm wzrosła o $18,42 \%$, natomiast mediana spadła o $37,76 \%$.

Następnie analizie zostały poddane wartości wskaźników uwzględniających dywidendy wypłacone przez spółki, tj. wskaźnik stopy dywidendy oraz wskaźnik wypłaty dywidendy w odniesieniu do rentowności kapitału własnego emitentów. Wraz ze wzrostem ROE w ostatnim roku przed wypłatą dywidendy, a także w okresie wypłaty stopa dywidendy badanych jednostek rosła.

Porównując wskaźnik wypłaty dywidendy i ROE z roku poprzedzającego wypłatę, zauważa się negatywną zależność między tymi wartościami, jednak biorąc pod uwagę rentowność z okresu wypłaty, występuje bardzo słaba dodatnia korelacja.

W okresie przed wypłatą dywidendy spadkowi kapitału własnego towarzyszy wzrost kwoty dywidendy, natomiast w poprzednim roku nie występuje widoczna zależność między wartościami. W analizie korelacji kapitału własnego i płatności 
dywidend nie uwzględniono spółki Aqua ze względu na znacznie odstające wartości w porównaniu z pozostałymi spółkami.

Na podstawie opisanych analiz nie jest możliwe jednoznaczne stwierdzenie występowania zależności między danymi fundamentalnymi a polityką dywidend w badanej próbie. Średni wiek spółki, wynoszący 18 lat, wskazuje na to, że nie są to podmioty w początkowej fazie rozwoju, lecz mające ustabilizowany biznes. Do najmłodszych spółek znajdujących się w próbie należą Onico (2009 r.), Euro-Tax.pl (2008 r.), PGS Software (2005 r.).

\section{Sygnalizacja przyszłych wyników przez zmianę dywidend}

W celu zbadania wpływu zmiany w polityce dywidend na wyniki emitentów analizie poddano czynniki fundamentalne wszystkich spółek na koniec każdego roku, w którym nastąpiła wypłata dywidendy. Uwzględnionymi w badaniach wartościami były przychody, zysk operacyjny, zysk netto, rentowność kapitału własnego oraz marża operacyjna. Następnie zmiany wysokości cech fundamentalnych zestawiono ze zmianą czynników powiązanych z wielkością wypłacanej dywidendy, tj. kwotą dywidendy oraz takimi wskaźnikami jak: dywidenda na akcję (DPS - dividend per share), wskaźnik wypłaty dywidendy (DPR - dividend payout ratio) i stopa dywidendy (DY - dividend yield). Czynniki te przedstawiono w podziale na ujemne i dodatnie zmiany wartości oraz ich wysokość ogółem, która uwzględnia dodatkowo brak zmiany wysokości poszczególnych parametrów. W zestawieniu pominięto wartości znacznie odstające od pozostałych. Podsumowanie wartości przedstawiono w tabeli 2.

Analiza wyników regresji wskazuje, że zmiana wysokości dywidendy nie oddziałuje silnie na zmianę czynników fundamentalnych. We wszystkich przypadkach wartość parametru $\mathrm{R}^{2}$ jest dosyć niska, przy czym najwyższa jest $\mathrm{w}$ przypadku zmniejszenia dywidendy i zmiany zysku netto. Współczynnik kierunkowy dla wszystkich parametrów, z wyjątkiem marży operacyjnej, jest ujemny i osiąga najwyższą wartość po porównaniu zmiany wynikającej z obniżenia wartości dywidendy z zyskiem operacyjnym i zyskiem netto.

Zestawienie wskaźnika DPS z wykorzystanymi cechami fundamentalnymi przynosi analogiczne rezultaty do analizy zmian kwot dywidendy. Współczynnik determinacji $\mathrm{R}^{2}$ dla wszystkich przypadków jest niewielki, przy czym największą wartość przyjmuje dla zysku netto i spadku DPS. Współczynnik kierunkowy jest dodatni jedynie dla marży operacyjnej oraz dla zysku netto przy wzroście wysokości DPS, jednak ich wielkości są bardzo małe.

Dla zmiany DPS oraz kwoty dywidendy wyniki są spójne z teorią sygnalizacji jedynie w przypadku spadku zmiany tych wartości w zestawieniu z przychodami, zyskiem operacyjnym, zyskiem netto i ROE. Wyjątek stanowi marża EBIT, dla której z kolei kierunek zmiany jest zgodny z teorią sygnalizacji dla przyrostu kwoty dywidendy i DPS oraz zmiany tych wartości ogółem. 
Tabela 2. Zestawienie czynników fundamentalnych i zmian wielkości wypłacanej dywidendy

\begin{tabular}{|c|c|c|c|c|c|}
\hline \multirow{2}{*}{ Dywidenda } & Przychody & EBIT & Zysk netto & ROE & Marża EBIT \\
\hline & \multicolumn{5}{|c|}{ Współczynnik kierunkowy } \\
\hline Dywidenda ogółem & 0,0003 & $-0,1917$ & $-0,2150$ & $-0,0164$ & 0,0259 \\
\hline Zmniejszenie dywidendy & $-0,3108$ & $-2,0068$ & $-3,2824$ & $-0,1696$ & 0,0722 \\
\hline \multirow[t]{2}{*}{ Zwiększenie dywidendy } & $-0,0276$ & $-0,1707$ & $-0,0737$ & $-0,0289$ & 0,0143 \\
\hline & \multicolumn{5}{|c|}{$\mathrm{R}^{2}$} \\
\hline Dywidenda ogółem & 0,00000 & 0,01398 & 0,02150 & 0,00874 & 0,06485 \\
\hline Zmniejszenie dywidendy & 0,03850 & 0,07168 & 0,25234 & 0,05880 & 0,04127 \\
\hline Zwiększenie dywidendy & 0,01053 & 0,02795 & 0,00526 & 0,03351 & 0,02464 \\
\hline \multirow{2}{*}{ DPS } & Przychody & EBIT & Zysk netto & ROE & Marża EBIT \\
\hline & \multicolumn{5}{|c|}{ Współczynnik kierunkowy } \\
\hline DPS ogółem & $-0,0159$ & $-0,1020$ & $-0,1348$ & $-0,0169$ & 0,0260 \\
\hline Spadek DPS & $-0,2487$ & $-1,3482$ & $-2,4339$ & $-0,1268$ & 0,0621 \\
\hline \multirow[t]{2}{*}{ Wzrost DPS } & $-0,0076$ & $-0,0752$ & 0,0113 & $-0,0333$ & 0,0107 \\
\hline & \multicolumn{5}{|c|}{$\mathrm{R}^{2}$} \\
\hline DPS ogółem & 0,00189 & 0,00393 & 0,00839 & 0,00916 & 0,06505 \\
\hline Spadek DPS & 0,02765 & 0,03679 & 0,15648 & 0,03651 & 0,03430 \\
\hline Wzrost DPS & 0,00181 & 0,00820 & 0,00016 & 0,04835 & 0,01741 \\
\hline \multirow{2}{*}{ DPR } & Przychody & EBIT & Zysk netto & ROE & Marża EBIT \\
\hline & \multicolumn{5}{|c|}{ Współczynnik kierunkowy } \\
\hline DPR ogółem & $-0,0316$ & $-0,3028$ & $-0,3133$ & $-0,0380$ & $-0,0041$ \\
\hline Spadek DPR & $-0,0069$ & 0,6481 & 0,4455 & $-0,0213$ & $-0,0163$ \\
\hline \multirow[t]{2}{*}{ Wzrost DPR } & $-0,0095$ & $-0,2205$ & $-0,1971$ & $-0,0239$ & $-0,0050$ \\
\hline & \multicolumn{5}{|c|}{$\mathrm{R}^{2}$} \\
\hline DPR ogółem & 0,02322 & 0,10612 & 0,13896 & 0,13643 & 0,00515 \\
\hline Spadek DPR & 0,00008 & 0,03847 & 0,02337 & 0,00541 & 0,00879 \\
\hline Wzrost DPR & 0,00672 & 0,32772 & 0,35792 & 0,06784 & 0,00813 \\
\hline \multirow{2}{*}{ DY } & Przychody & EBIT & Zysk netto & ROE & Marża EBIT \\
\hline & \multicolumn{5}{|c|}{ Współczynnik kierunkowy } \\
\hline DY ogółem & $-0,0264$ & $-0,0595$ & $-0,0715$ & $-0,0074$ & 0,0049 \\
\hline Spadek DY & $-0,0344$ & 0,4107 & 0,3693 & 0,0230 & 0,0151 \\
\hline \multirow[t]{2}{*}{ Wzrost DY } & 0,0264 & $-0,0968$ & $-0,0739$ & 0,0184 & 0,0042 \\
\hline & \multicolumn{5}{|c|}{$\mathrm{R}^{2}$} \\
\hline DY ogółem & 0,03329 & 0,00875 & 0,01543 & 0,01128 & 0,01445 \\
\hline Spadek DY & 0,01841 & 0,13716 & 0,14118 & 0,05731 & 0,06304 \\
\hline Wzrost DY & 0,10231 & 0,10140 & 0,08556 & 0,07065 & 0,00863 \\
\hline
\end{tabular}

Źródło: opracowanie własne. 
$\mathrm{R}^{2}$ dla wskaźnika stopy wypłaty dywidendy przyjmuje najwyższe wartości dla EBIT i zysku netto w sytuacji, gdy zmiana wskaźnika DPR jest dodatnia. Wszystkie uzyskane wielkości $\mathrm{R}^{2}$ wskazują na bardzo nieznaczny wpływ zmiany DPR na analizowane cechy fundamentalne spółek. Współczynnik kierunkowy jest na niskim i ujemnym poziomie dla wszystkich przypadków, z wyjątkiem zysku operacyjnego i zysku netto w sytuacji, gdy zmiana DPR jest negatywna, i jedynie w tych przypadkach wyniki są zgodne z teorią sygnalizacji.

Analiza $\mathrm{R}^{2}$ dla zmiany stopy dywidendy wskazuje, że jej zmiana ma niewielki wpływ na zmianę porównywanych parametrów. $\mathrm{R}^{2}$ przyjmuje największą wartość dla zysku operacyjnego i zysku netto przy negatywnej zmianie DY. Tak jak w poprzednich przypadkach wartości współczynnika kierunkowego dla wszystkich czynników są bardzo niskie. Dodatnie wyniki uzyskano dla wszystkich parametrów w przypadku dodatniej zmiany DY, dla marży EBIT dodatkowo dla zmiany DY ogółem.

Uzyskane wyniki wskazują, że zmiany wysokości dywidendy i bazujących na dywidendzie wskaźników nie uzasadniają zmian wyników finansowych emitentów. Mimo że w części przypadków wartości wskaźników kierunkowych są zgodne $\mathrm{z}$ teorią sygnalizacji, niskie wartości współczynnika determinacji $\mathrm{R}^{2}$ wskazują, że zmiany dywidendy w niewielkim stopniu wyjaśniają zmienność cech fundamentalnych spółek, co nie pozwala na potwierdzenie teorii sygnalizacji wyników za pomocą dywidend.

\section{Sygnalizacja zmian cen przez zmianę dywidend}

W celu zbadania reakcji rynku na ogłoszenie wypłaty dywidendy przez wybrane spółki zestawiono zmiany wysokości wypłacanych przez nie w danych latach dywidend ze stopami zwrotu uzyskanymi z inwestycji w akcje emitentów.

$\mathrm{Na}$ datę wystąpienia zdarzenia $(d)$, będącego bazą do obliczenia stóp zwrotu, wybrano dzień ogłoszenia przez zarząd uchwały o wypłacie dywidendy. Na potrzeby analizy zebrano ceny akcji poszczególnych spółek oraz wartości indeksu NCIndex z dnia $d$ oraz 1, 7 i 25 dni przed tą datą i po tej dacie. Czynność tę powtórzono dla każdego roku, w którym występowała wypłata dywidendy przez wybrane przedsiębiorstwa. Wykorzystując zgromadzone dane, obliczono dwa rodzaje stóp zwrotu. Prosta stopa zwrotu pokazuje reakcje inwestorów, które mogą wynikać z ogólnej tendencji do zmiany cen na rynku, kiedy emocje inwestorów pod wpływem czynników zewnętrznych wpłynęły na zachowania cen akcji. Nadwyżkowe stopy zwrotu typu buy-and-hold (BHR) odzwierciedlają reakcję inwestorów na rynku akcji danej spółki po skorygowaniu o zmianę ceny wynikającej z zachowania całego rynku. Jako benchmark przyjęto NCIndex obejmujący wszystkie akcje spółek notowanych na NewConnect ${ }^{1}$. Oba rodzaje stóp zwrotu wyznaczono na następu-

${ }^{1}$ NCIndex obejmuje spółki, których free float jest wyższy niż 10\%, a wartość akcji w wolnym obrocie wynosi minimum $1 \mathrm{mln}$ zł i które nie są zakwalifikowane do NC HLR lub NC SHLR. 
jące okresy: $d-25, d-7, d-1, d+1, d+7, d+25$. Obliczenie BHR przeprowadzono za pomocą wzoru [Ljungqvist 1997, s. 1331]:

$$
B H R=\sum\left(\ln \frac{P_{t+1}}{P_{t}}-\ln \frac{I_{t+1}}{I_{t}}\right),
$$

gdzie: $P_{t+1}-$ wartość akcji w okresie $t+1$,

$P_{t} \quad$ - wartość akcji w okresie $t$,

$I_{t+1}-$ wartość indeksu w okresie $t+1$,

$I_{t} \quad$ - wartość indeksu w okresie $t$.

$$
\text { Prosta stopa zwrotu }=\frac{P_{t+1}}{P_{t}}-1
$$

Zestawienie wyników uzyskanych dla obu rodzajów stóp zwrotu z danych okresów przedstawiono w tabeli 3.

Tabela 3. Prosta stopa zwrotu i nadwyżkowa stopa zwrotu typu buy-and-hold

\begin{tabular}{|l|r|r|r|r|r|r|}
\hline \multirow{2}{*}{ Wyszczególnienie } & $d-25$ & $d-7$ & $d-1$ & $d+1$ & $d+7$ & $d+25$ \\
\cline { 2 - 7 } & \multicolumn{7}{|c|}{ Prosta stopa zwrotu } \\
\hline Średnia & $2,67 \%$ & $1,82 \%$ & $1,05 \%$ & $0,45 \%$ & $1,53 \%$ & $4,62 \%$ \\
\hline Odchylenie standardowe & $11,88 \%$ & $6,55 \%$ & $4,37 \%$ & $4,42 \%$ & $6,98 \%$ & $10,53 \%$ \\
\hline Mediana & $1,81 \%$ & $0,23 \%$ & $0,00 \%$ & $0,00 \%$ & $0,00 \%$ & $3,38 \%$ \\
\hline Kwartyl 1 & $-4,73 \%$ & $-0,67 \%$ & $0,00 \%$ & $-0,09 \%$ & $-1,06 \%$ & $-1,22 \%$ \\
\hline Kwartyl 3 & $8,75 \%$ & $5,05 \%$ & $1,50 \%$ & $0,68 \%$ & $3,45 \%$ & $8,67 \%$ \\
\hline & \multicolumn{7}{|c|}{ BHR } \\
\hline Średnia & $4,60 \%$ & $2,11 \%$ & $1,08 \%$ & $0,36 \%$ & $1,84 \%$ & $6,07 \%$ \\
\hline Odchylenie standardowe & $11,48 \%$ & $6,46 \%$ & $4,26 \%$ & $4,40 \%$ & $6,79 \%$ & $10,09 \%$ \\
\hline Mediana & $4,54 \%$ & $0,99 \%$ & $0,39 \%$ & $0,00 \%$ & $1,15 \%$ & $4,18 \%$ \\
\hline Kwartyl 1 & $-1,83 \%$ & $-1,06 \%$ & $-0,51 \%$ & $-0,83 \%$ & $-1,62 \%$ & $0,06 \%$ \\
\hline Kwartyl 3 & $10,85 \%$ & $5,47 \%$ & $1,89 \%$ & $1,18 \%$ & $5,12 \%$ & $11,59 \%$ \\
\hline
\end{tabular}

Źródło: opracowanie własne.

Ograniczeniem, które napotkano w czasie gromadzenia danych, była niska płynność akcji notowanych na NewConnect spółek. Na podstawie wielkości średnich stóp zwrotu można zauważyć, że ich wartości zwiększają się wraz z wydłużeniem okresu analizy. Dla dwudziestopięciodniowego przedziału czasowego reakcja rynku jest większa po ogłoszeniu informacji o wypłacie dywidendy, kiedy uzyskano 4,62-procentowy zwrot z inwestycji w porównaniu ze zwrotem wynoszącym 2,67\% w przypadku inwestycji na 25 dni przed zdarzeniem. Średnia wartość BHR dla tego okresu wskazuje, że badana grupa spółek przyniosła 6,07\% zysku powyżej stopy zwrotu uzyskanej z indeksu NCIndex w okresie $d+25$, a natomiast $4,60 \%-$ w okre- 
sie $d-25$. W krótszych przedziałach czasowych, tj. siedmio- i jednodniowych, wyższe stopy zwrotu uzyskane są w sytuacji, gdy inwestycja została podjęta przed ogłoszeniem uchwały o dywidendzie. Dla okresu $d-7$ średnie wartości dla prostej stopy zwrotu i BHR wyniosły odpowiednio $1,82 \%$ i $2,11 \%$, a dla $d+7-1,53 \%$ i $1,84 \%$. Najmniejszy zwrot z inwestycji uzyskano na jeden dzień po ogłoszeniu informacji o wypłacie dywidendy. Wartość prostej stopy zwrotu wyniosła jedynie $0,45 \%$, a BHR - 0,36\% powyżej inwestycji w NCIndex. Wyniki wskazują, że w tak krótkim okresie uchwała o wypłacie dywidendy nie jest dla akcjonariuszy znaczącym źródłem informacji sygnalizującym sytuację spółki. Ryzyko inwestycji odzwierciedlone za pomocą odchylenia standardowego $\mathrm{w}$ przypadku obu zastosowanych sposobów liczenia stóp zwrotu w okresie siedmio- i jednodniowym jest na zbliżonym poziomie w okresach przed ogłoszeniem i po ogłoszeniu uchwały o wypłacie dywidendy. Różnica wartości zwiększa się dla najdłuższego okresu, kiedy wynoszą one 11,88\% $(d-25)$ i $10,55 \%(d+25)$ dla prostej stopy zwrotu oraz $11,48 \%(d-25)$ i $10,09 \%$ $(d+25)$ dla BHR.

W następnej kolejności wartości obliczonych stóp zwrotu porównano ze zmianą wysokości wypłaconej w danym roku dywidendy w stosunku do kwoty wypłaty z poprzedniego okresu. Po odrzuceniu zmiennych znacznie odstających od pozostałych wartości obliczone zostały modele regresji metodą najmniejszych kwadratów, których wyniki przedstawione zostały w tabeli 4. Współczynniki kierunkowe we wszystkich analizowanych przypadkach, z wyjątkiem okresu $d-1$, przyjmują wartość ujemną. Oznacza to, że wraz ze wzrostem kwoty wypłacanej dywidendy stopy zwrotu maleją. Takie zachowanie rynku jest niezgodne z teorią sygnalizacji. Może to sugerować, że inwestorzy oczekują zatrzymania wypracowanych przez spółki zysków, czyli ich dalszego rozwoju.

Tabela 4. Parametry modeli regresji

\begin{tabular}{|l|c|c|c|c|c|c|}
\hline \multicolumn{1}{|c|}{ Okresy } & $\mathrm{a}$ & $\mathrm{b}$ & $\mathrm{R}^{2}$ & $\mathrm{a}$ & $\mathrm{b}$ & $\mathrm{R}^{2}$ \\
\hline \multicolumn{7}{|c|}{ Prosta stopa zwrotu } \\
\hline$d-1$ & 0,7641 & 0,4141 & 0,0014 & 1,9642 & 0,4036 & 0,0086 \\
\hline$d+1$ & $-1,9903$ & 0,4288 & 0,0092 & $-2,0130$ & 0,4277 & 0,0091 \\
\hline$d-7$ & $-0,5515$ & 0,4301 & 0,0014 & $-0,0447$ & 0,4220 & 0,0000 \\
\hline$d+7$ & $-1,7677$ & 0,4547 & 0,0178 & $-1,4201$ & 0,4559 & 0,0106 \\
\hline$d-25$ & $-1,1700$ & 0,4436 & 0,0226 & $-1,1965$ & 0,4713 & 0,0222 \\
\hline$d+25$ & $-0,5043$ & 0,4483 & 0,0034 & $-0,0435$ & 0,4243 & 0,0000 \\
\hline
\end{tabular}

Źródło: opracowanie własne.

Zmiana wysokości dywidendy nie wyjaśnia w znacznym stopniu zmian cen w okresie od jednego dnia do miesiąca. Nie można również zauważyć istotnej reakcji rynku przed ogłoszeniem informacji o wypłacie dywidend, co może sugerować, że inwestorzy uzyskują informacje o zmianie dywidendy z innych źródeł niż uchwa- 
ły zarządu. Być może przyczyną takiego zachowania inwestorów jest niski free float, co w efekcie prowadzi do niewielkiego zainteresowania inwestorów spółką. Możliwe również, że komunikat o uchwale dotyczącej podziału zysku nie jest informacją nową dla inwestorów, która zmieniałaby ich postrzeganie spółki.

\section{Podsumowanie}

Podsumowując przeprowadzone badania, można stwierdzić, że w badanej próbie występuje jedynie niewielka zależność pomiędzy:

- zmniejszeniem zmiany kwoty dywidendy i DPS a przychodami, EBIT, zyskiem netto i ROE,

- zwiększeniem zmiany dywidendy i DPS oraz zmianą dywidendy i DPS ogółem a marżą EBIT,

- spadkiem zmiany DPR a przychodami, ROE i marżą EBIT,

- zmianą DY ogółem a marżą EBIT,

- spadkiem zmiany DY a przychodami,

- wzrostem zmiany DY a przychodami, EBIT, zyskiem netto, ROE i marżą EBIT. Analiza zmian stóp zwrotu przed ogłoszeniem uchwały o wypłacie dywidendy i po nim nie potwierdza istotnej zależności między wypłatą dywidendy a zmianą cen akcji.

Wyniki pokazują, iż polityka dywidend wśród podmiotów notowanych na NewConnect nie ma na celu sygnalizowania przyszłych wyników. Może to wynikać z relatywnie małej wielkości spółek i ich dość dużej wrażliwości na zmiany w otoczeniu, które nie zależą od zarządów, dlatego te ostatnie nie uwzględniają w polityce dywidend przyszłych wyników. Okres funkcjonowania nakładał się na bardzo burzliwe i zmienne otoczenie, co również nie sprzyjało prognozowaniu przyszłych wyników. Ograniczeniem wniosków była również liczebność próby oraz relatywnie dość krótki horyzont badania.

\section{Literatura}

Aharony J., Swary I., 1980, Quarterly dividend and earnings announcements and stockholders' returns: An empirical analysis, The Journal of Finance, vol. 35, no. 1.

Allen F., Michaely R., 2003, Payout policy, Handbook of the Economics of Finance, vol. 1A.

Amihud Y., Murgia M., 1997, Dividends, Taxes, and signaling: Evidence from Germany, The Journal of Finance, vol. 52, no. 1.

Asquith P., Mullins D.W., 1983, The impact of initiating dividend payments on shareholders'wealth, The Journal of Business, vol. 56, no. 1.

Bhattacharya S., 1979, Imperfect information, dividend policy, and "the bird in the hand" fallacy, The Bell Journal of Economics, vol. 10, no. 1.

Cowan A.R., Sant R., 1994, Do dividends signal earnings? The case of omitted dividends, Journal of Banking and Finance, vol. 18, no. 6. 
Dielman T.E., Oppenheimer H.R., 1984, An examination of investor behavior during periods of large dividend changes, The Journal of Financial and Quantitative Analysis, vol. 19, no. 2.

Gou Y., Maung M., Wilson C., 2015, Dividend Changes and Future Profitability: The Role of Earnings Volatility, University of Saskatchewan.

Grullon G., Michaely M., Swaminathan B., 2002, Are dividend changes a sign of firm maturity?, Journal of Business, vol. 75, no. 3.

Healy P., Palepu K., 1988, Earning information conveyed by dividend initiations and omissions, Journal of Financial Economics, no. 2.

Lang L.H., Litzenberger R.H., 1989, Dividend announcements. Cash flow signalling vs. free cash flow hypothesis?, Journal of Financial Economics, no. 24.

Laub M., 1976, On the informational content of dividends, The Journal of Business, vol. 49, no. 1.

Lintner J., 1956, Distribution of incomes of corporations among dividends, retained earnings, and taxes, The American Economic Review, vol. 46, no. 2.

Ljungqvist A.P., 1997, Pricing initial public offering: Further evidence from Germany, European Economic Review, no. 41.

Michaely R., Thaler R., Womack K., 1995, Price reactions to dividend initiations and omissions: Overreaction or drift?, The Journal of Finance, vol. 50, no. 2.

Miller M., Modigliani F., 1961, Dividend policy, growth, and valuation of shares, The Journal of Business, vol. 34, no. 4.

Miller M., Rock K., 1985, Dividend policy under asymmetric information, The Journal of Finance, vol. 40 , no. 4 .

Pettit R.R., 1972, Dividend announcements, security performance, and capital market efficiency, The Journal of Finance, vol. 27, no. 5.

Watts R., 1973, The information content of dividends, The Journal of Business, vol. 46, no. 2.

Woolridge J.R., 1983, Dividend changes and security prices, The Journal of Finance, vol. 38, no. 5. 